\title{
SMPIT Alam Nurul Islam: Building Affection Through Implementation of Islamic Religious Education (Study of Implementation of Islamic Education in SMPIT Alam Nurul Islam Yogyakarta)
}

\author{
Mulyani Mudis Taruna ${ }^{1}$, Abdul Rohman ${ }^{2}$ \\ \{tarunamulyani@gmail.com ${ }^{1}$,rohman_mudis@yahoo.com ${ }^{2}$ \} \\ Office of Religious Research and Development, Ministry of Religious Affairs Republic Indonesia, \\ Semarang, Indonesia ${ }^{1}$ \\ Lecturer in the Faculty of Social and Political Sciences, Jenderal Soedirman University, Purwokerto, \\ Central Java ${ }^{2}$
}

\begin{abstract}
The title of the research is "SMPIT Alam Nurul Islam; Building Affection through Islamic Religious Education." Problems formulation were; 1) How is the implementation of Islamic education in SMPIT Alam Nurul Islam, 2) How is the development of PAI curriculum integrated-based in building affection within students, 3 ) How are the model of extra-curricular activities developed by SMPIT Alam Nurul Islam, and 4) What are the supporting and hampering factors in the implementation of integrated learning in SMPIT Alam Nurul Islam. The findings were 1) the implementation of Islamic religious education at SMPIT Alam Nurul Islam refers to the standard curriculum of the Ministry of Education and Culture, JSIT, and JSAN, 2) the development of the PAI curriculum integrated-based contributed to the development of affection of students through habituation, 3) the compatible extracurricular activities have been able to create the situation and conditions of learning with dynamic and fun, and 4) carrying capacity in PAI learning is cool natural conditions, Islamic habituation, and religious academic culture.
\end{abstract}

Keywords: SMPIT, JSAN, Islamic-integrated, Affection, Implementation.

\section{Introduction}

Formal education institutions always experience development and modification in curriculum designs and learning models. The term development and modification in formal educational institutions means the development of a "traditional" model of the educational institution with a top-down learning which designed to develops into "modern" with a learning designed by the Foundation (bottom-up). These developments are mainly in curriculum design and learning models, which integrate various aspects of curriculum, culture, environment (local content), nature, learning methods, and management integration that involve parents outside the school committee.

Providing an opportunity to formal educational institutions, especially the private sector, to make innovations is part of the Government's strategy to make changes to aspects of learning methods, due to the demands of modernity and global competition in the world of education. According to Leo Buscagila in Andrias Harefa, the change is the final result of all 
real learning processes [6]. Also, in the world of formal education, there will always continuous be changing without stopping. This change in the world of education is not only in public and private formal educational institutions but also in religious-educational institutions, such as Islamic-integrated schools.

Islamic-Integrated schools in Indonesia are historical realities that continue to receive widespread acceptance from the Muslim community. Especially, after the establishment of the Islamic-Integrated School Network (JSIT) Indonesia, that was established on July 30, 2003, the organization spread the information to regions and increases the desire of the community to organize an Islamic-integrated school. The vision of JSIT is to become a center for mobilizing and empowering Islamic-integrated schools towards effective and quality schools (Muhammad Ali, HNW: Sekolah Islam Terpadu Kelanjutan Realitas Sejarah. Http://www.liputan6.com), accessed on September 13, 2018.

This historical reality invites a positive reaction, especially the experts in Islamic education who feel "fidgety" with the condition of formal educational institutions that do not pay attention to aspects of the character from the perspective of the Islamic religion. But, the historical reality also has an exclusive impression because it organizes an average of high capital owners. Then, the schools need funding from parents. Islamic-Integrated schools have the impression as elitist and exclusive for rich children, both for boarding school models and full-day schools.

The Islamic-Integrated School (SIT) is not a formal educational institution that deviates from the model developed by the Ministry of National Education or the Ministry of Religion. Islamic-Integrated School is also not an institution that competes with formal schools under mainstream organizations such as Muhammadiyah, Nahdlotul 'Ulama, Al Irsyad, etc. The reason is, SIT is a school that tries to implement an implementation approach that combines general education and religious education into an integrated curriculum. Thus, it still refers to the national curriculum developed by the Ministry of National Education [8]. According to [9], SIT is essentially a school that implements the concept of Islamic education based on the Qur'an and Sunnah, and is based on the National Education System Law. The operational concept of SIT is an accumulation of the process of civilizing, inheriting and developing the Islamic teachings, Islamic culture, and civilization from generation to generation. The term "integrated" is intended to strengthen Islam. Means, Islam is perceived as whole, comprehensive, integral, not partial, and syumuliyah not juz'iyah [9].

By the concept of SIT, it illustrates that the offered educational program is trying to integrate general education with Islamic education aiming children as students have the quality of public education and adequate religious education. This is different from Islamic educational institutions that offer additional programs such as BTA (Read, Write the Qur'an), Mabit (Malam Bina Iman and Taqwa), habituation to read Al Quran before class every Friday, and activities religion to supports Islamic Religious Education which is considered still not enough.

In general, Islamic-integrated schools are a breakthrough in the world of education that reinforces the values of Islamic teachings in the general education system under the Ministry of National Education. There might be several considerations of parents by sending their children to Islamic- integrated schools, such as feeling "fidgety" with a common formal education model with less of religious education, in spite they do not want to submit their children to Islamic boarding schools, quite intensive of religious studies and same on the general subject from public schools. The flagship program of Islamic-integrated schools that provides a nuance of novelty and not boring is also a factor for parents sending their children to Islamic-integrated schools. 
Based on various reasons for the desire of parents sending their children to Islamic integrated schools is a standard reason based on reality. However, there are substantial reasons and might play as the main reason; they assume the Islamic- integrated schools succeed in producing students who not only with intelligence and heart but can adapt within the scope of Indonesia and Islam. Therefore, Islamic- integrated schools, according to the author's the opinion, the school has been able to build the affection of students, especially through the development of Islamic Religious Education with various developed activities.

According to community interest in Islamic-integrated schools and a variety of excellent programs, it needs to conduct a study through research. Based on the background, particular research focuses on the title "SMPIT Alam Nurul Islam; Building Affection through Islamic Religious Education." The focus of the research is; how the curriculum is implemented and developed by SMPIT Alam Nurul Islam in the implementation of Islamic Religious Education. The structured formulations of the problem are;

1. How is the implementation of Islamic education in SMPIT Alam Nurul Islam?

2. How is the development of curriculum integrated-based in compiling syllabi, lesson plans, and learning methods at SMPIT Alam Nurul Islam?

3. What are the variants of extra-curricular activities that are relevant to Islamic religious education at SMPIT Alam Nurul Islam?

4. What are the supporting and hampering factors in the implementation of integrated learning in SMPIT Alam Nurul Islam?

\section{Literature review}

1. Research by Muhammad Jadid entitled "the Internalization of Islamic Values in Learning Islamic Religious Education on Class VIII at SMPIT Alam Nurul Islam Sleman"; found out that the concept of internalizing Islamic values carried out during teaching and learning activities. The internalized Islamic values were religious, devoted to parents and teachers, respect, compassion, diligent, orderly, cleanliness, and polite values.

2. Research by Danang Pari Yudhono entitled "Analysis and Design of Library Information System at SMPIT Alam Nurul Islam Yogyakarta" obtained information that the library system is poor of effective where data taking and reports still use pen and books. However, in some cases, computerization has implemented so that the storage of the database has integrated and minimizes the possibility of lost and damaged data.

3. Research by Tri Endang Sumiyarsih entitled "The Concept of Nature Schools in SMPIT Alam Nurul Islam Yogyakarta in terms of Interior and Learning Activities," found out that (1) SMPIT Alam Nurul Islam uses nature-based learning, (2) In addition to aspects of morals, knowledge, leadership and entrepreneurship as a curriculum, also aspects of nature as a medium of learning. (3) Interior building elements (floors, walls, ceilings, doors, windows, stairs) using building materials from nature (woven bamboo and coconut wood), and (4) processing of spatial conditions (lighting, acceleration, acoustics) optimize the use of natural sources.

\subsection{Integration of Islamic Education in Islamic Integrated School}

A millennial generation or Y-generation in various work of literature is the 1990-2000 generation with birth spans in 1981 - 1994 and also defines as a generation that is familiar 
with technologies such as computers, laptops, smartphones, video games and various other accessories related to information technology. Today, it has entered the Z-generation or Netgeneration with a birth span of 1995 - 2010 as the generation after Y-generation that they capable to apply all activities at one time such as tweeting using cellphones and browsing using a PC (https://id.wikipedia.org/ wiki / Generasi_Z), accessed on 17 September 2018).

Schools as formal educational institutions are required to create a dynamic generation, such as Y-generation. According to Mochtar Buchori, the young generation must be trained to move dynamically among 4 contexts in dealing with national problems, namely local, national, regional and global. Thus, problems demand a new outlook, a new attitude, a new mentality within the younger generation because the changes in the future will be marked by an explosion of knowledge and information [1]. Apart from schools, there are no institutions that have the optimal ability to create the generation into the dynamic and civilized millennial generation.

According to [2], Education is a cultural process that forms the nation's character to be more civilized, uphold the values of truth, honesty, social sensitivity, solidarity, and nonviolence. Education is not only defined as reading and writing activities in the classroom or the process of indoctrination by the authorities to its citizens. The view of Darmaningtyas becomes coherent if the curriculum developed by educational institutions supports the process of character formation and accommodates various aspirations of the education community in general. Therefore, education will not necessarily contain a variety of curriculum that support the process of forming a more civilized culture and being able to adapt to the conditions of science and technology.

To face the challenges of the times and millennial times, the developed curriculum, at least, can accommodate the aspirations of the people, while, at the same time, respond the challenges of the times. The curriculum in schools not only maintains the traditional curriculum but becomes a progressive curriculum that always tries to change the environment into a better world. The curriculum must always be changed because of the changes in society due to advances in science and technology. The curriculum change runs continuously or it will be out of date [3]. The role of the curriculum for formal schools is the main "capital" to process all planned learning activities. The curriculum has a role not only in conservative and critical or evaluative roles but also in creative roles.

The role of the conservative put a curriculum to transform and interpret social heritage to the young generation that schools play as a social institution to influence and foster student behavior refers to the social values of society. Also, it should always be in line with the role of education as a social process. The critical or evaluative role is to put the curriculum to take an active part in social control and emphasize the element of critical thinking when the social values that are not in line with future conditions are eliminated and performed the modifications and improvements. The creative role is the curriculum's role in carrying out various creative and constructive activities by creating and compiling a new thing following the needs of the present and the future [5].

Structurally, the curriculum must follow the regulation of the Government (Ministry of National Education for public schools and the Ministry of Religion for Madrasah/Islamic School). However, each school is given the flexibility to "creating" the curriculum in line with the goals. According to [3], the formulated curriculum can't be separated from the underlying principles, such as the philosophical, psychological, sociological, and organizational principles. Philosophical principles related to educational goals that the school aims to educate children to be a good human being, psychological principles aims to predict the factors of children in the curriculum, such as psychological children, developmental children, 
psychology of learning, and the learning process of children, sociological principles where the curriculum must consider the style of values, norms, customs in a society where the children live, and organizational principles where the curriculum presented into separated subjects, and a relationship between the lessons or efforts to develop deeper relationships by eliminating all subject boundaries in an integrated curriculum [3].

The strength of the curriculum in the millennial era also considers the value of the curriculum function. The factor is caused, in the world of formal education; the curriculum becomes one of the most important factors for delivering knowledge to students through a measured and systematic learning process. Knowledge is a particular experience process that aims to create continuous changes in behavior or thinking, and learning is a systematic effort to enables the creation of education [4].

\subsection{The Curriculum of Islamic Education (PAI) in Islamic-integrated schools}

In public and private schools, religious education curriculum is one of the compulsory subjects with a minimum duration of 3 hours in one week. According to regulation number 20 of 2003 concerning the National Education System, Chapter V article 12 (1.a), stated that every student in each education unit is entitled to receive religious education following the religion and taught by educators of the same religion. This article is clearly stated that the religious education curriculum is a must for every school because religious education is the basis for students to have attitudes, personalities, and skills following with morality based on religious teachings.

In the Regulation of Republic of Indonesia, Number 55 of 2007 Concerning Religious Education, Chapter I in General Term, Article 1, stated that religious education is education that provides knowledge and forms the attitudes, personalities, and skills of students in practicing their religious teachings, which are implemented, at least, through subjects/lectures on all lines, levels and types of education. In Chapter II, Article 2, also stated that (1) Religious education functions to form Indonesian people who have faith and devoted to God Almighty and have good character and maintain peace and harmony in inter and interfaith religious relations. (2) Religious education aims to develop the ability of students to understand, appreciate, and practice the religious values that harmonize mastery among science, technology, and art.

Generally, the Religious Education curriculum is structured according to the school level from elementary and secondary levels. Curriculum preparation according to school level is carried out for the appropriate distribution of material taught at school level and grade level. Moreover, PP (Government Regulation) Number 55, article 5 paragraph (2), stated that religious education is taught following with the stages of mental development of students, and the implications are under the paragraph (3) stated that religious education encourages students to be obedient in performing religious teachings in daily life and put the religion as an ethical foundation and morals in personal life, family, community, nation, and state.

The importance of PAI in schools for Muslim students has changed from 2 hours to 3 hours in one week. An additional 1 hour of learning is expected to optimize the delivery of material while providing significant changing in student behavior following with the objectives of religious education. According to Leo Puscaqila, the change is the final result of all real learning processes [6]. And "learning" according to Ignas Kleden, basically, practices something, in spite, "learning about" only means knowing something [6].

The curriculum of religious education in Islamic-integrated schools, in general, is not only in the form of materials arranged in PAI subjects but is also integrated with other subjects and 
also integrated with programs formulated by schools. Schools are not just a place of learning for students to complete a set of curriculums, but schools are also educational institutions. According to Hidayat Nurwahid, education is a process of "humanizing" humans, and through education will educate into real noble of human beings because education will make civilized people [8].

Building the characteristics of the curriculum according to Abdurrahman An Nahlawi is that the curriculum must have a material teaching system harmony with human nature, must realize the objectives of fundamental Islamic education; purifying obedience and worship to Allah, every curriculum must be in accordance with the level of education, curriculum must pay attention to the goals of a realistic society, concerning life and starting from the ideal of Islam, the curriculum must be free from contradictions, referring to the unity of Islam and harmony with the psychological integrity that Allah the Almighty create for humans, the curriculum must be realistic to apply in harmony with the ability of the state, the curriculum must choose an elastic method to adapt to various conditions, environments, and conditions where the curriculum is implemented, the curriculum must be effective in providing behavioral educational-outcomes, and does not leave psychological-emotional impacts that harm the personality of students, and the curriculum must pay attention to direct activities that have high Islamic values, such as da'wah, providing services to the community, and jihad fi sabilillah [8].

In the context of the Islamic-Integrated School (SIT), the PAI lesson is not merely studying Islamic material in its context as 'ulum syar'iyyah (Jurisprudence or fiqh, worship, morals or ethic, and aqeedah or faith), but positioned as a religious lesson that provides a highly relevant framework of knowledge, attitudes and behavior, and needed in the context of present life. Several PAI concepts serve as a reference in the administration of education:

1. PAI has a struggling perspective; the affirmation of the importance of a high fighting spirit to defend the truth, justice, tyranny, evil, as ordered by Al Quran.

2. PAI with a national perspective; containing the values of love and defense to the motherland, always caring for the glory and prosperity of the nation and state.

3. PAI with a global perspective; making Islam as a religion to provide perspective, direction and ways in global life and conditions with advances in science, and technology that has implications to human (mu'amalah).

4. PAI with Science and Technology perspective; provide the appropriate framework for the development and use of science and technology for the benefit of life. The implication could balance to fikr and zikr, triggers and stimulates thinking and explore nature.

5. PAI has a democratic perspective; appreciation and respect for human values that are truly guaranteed in Islamic teachings.

6. PAI has a pluralist perspective; Islam accepts (tolerant) the diversity of ethnicity, culture, nation, and religion as a reality of life with considering the clear, firm, and final (qath'i) principles of faith [8].

\section{Research method}

The study used a qualitative approach. Then, the researcher as the main instrument should able to describe and elaborate all instruments related to the implementation of Islamic religious education, forms of curriculum development based on integration in the preparation of syllabi, lesson plans, learning methods, variants of extra-curricular activities relating to 
Islamic religious education, and find out the supporting and hampering factors in the implementation of integrated learning at SMPIT Alam Nurul Islam, Sleman, Yogyakarta.

The target of the research was SMPIT Alam Nurul Islam Godean, Sleman Yogyakarta. This school is used as a locus of research with consideration that it has graduated students, under the Ministry of National Education as well as has network with JSIT and JSAN, an integrated Nature school integrated with Islamic schools, and has a "Formula" curriculum from 3 institutions (Ministry of National Education, JSIT, and JSAN). Data collection techniques were interview, observation, and literature review.

Data analysis was performed cyclically and was natural since the preliminary study, data collection, and concluding. The analysis technique used analysis techniques developed by Milles and Hubberman, namely;

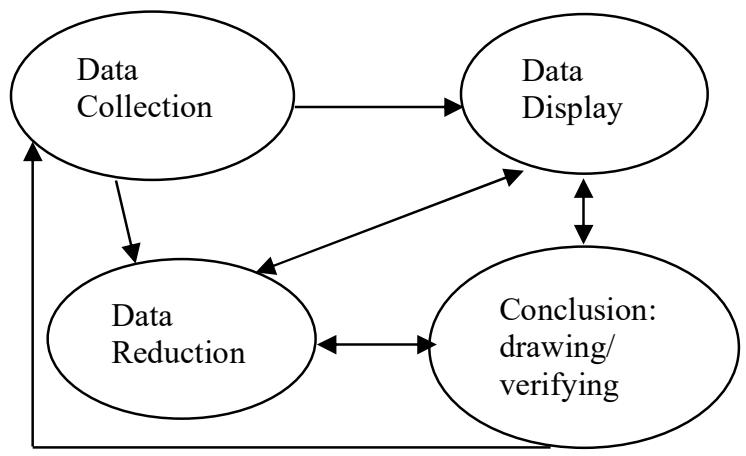

Fig. 1. Analysis techniques [10].

\section{Result}

\subsection{SMPIT Alam Nurul Islam Is not merely an Islamic education institution}

The existence of an Islamic-integrated school received a positive response from the community because it has a superior program that balances religion and science [7]. The big idea is about moral education without leaving the need for the development of science and skills, combining the values of revelation with the results of research into blended and unity learning. The purpose, the school will create a profile of students with comprehensive, academically qualified and mentally spiritual.

The paradigm of organizing an Islamic educational institution formulated by JSIT, apparently, requires another dimension as a step of improvement. The improvement performed by SMPIT Alam Nurul Islam. The school under the Nurul Islam Foundation places an inseparable nature in the administration of education. According to Muhammad Hamdani (Board of Education Foundation Management), nature can use as a more comprehensive learning method. The formulated paradigm is shown in Fig. 2. 


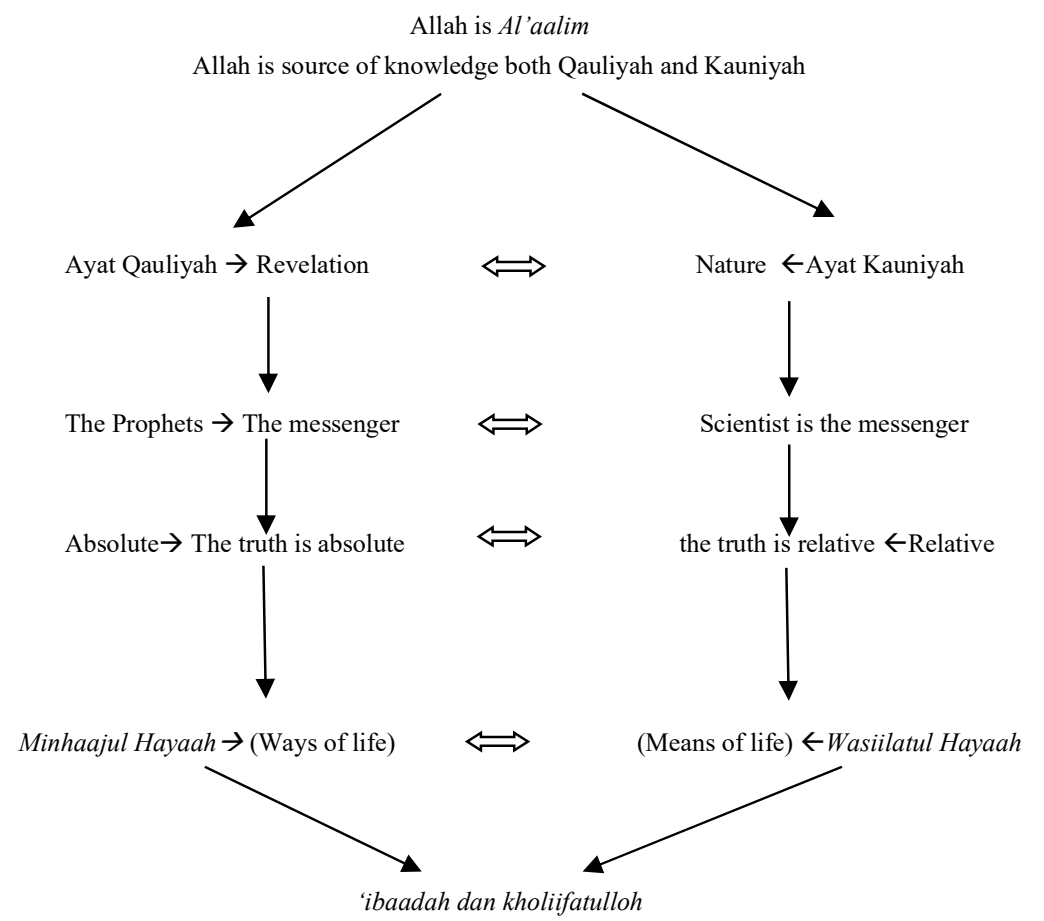

Fig. 2. Formulated paradigm

From the concept, Islamic education cannot be separated from its main source; Allah the Almighty. And, it gives to humans through the revelation and creation of nature. The school paradigm must refer to two things namely Qauliyah verses sourced from Allah and delivered through the Messenger of Allah with absolute truth and as a way of life. Not only the Qauliyah verse but also Kauniyah verses 6with natural signs derived from Allah and delivered by scientists whose the truth is relative and as a washilah (means) of human life. From the integration of qauliyah and kauniyah verses aims to form students who are obedient in worship and become khalifatu fi-alardli.

The paradigm becomes the basis and needs to understand first because the word of "IT" (Islamic-Integrated) related to the concepts (qauliyah and kauniyah) and must be the main foundation and become the school paradigm. This is because some IT schools are often trapped by the term of Islamic-Integrated with the concept of subjects integrated with Islamic values. Thus, when the learning process is not very clever in managing, there will be stagnation that unconsciously has committed a dichotomy, namely:

1. The dichotomy between religious and world-sciences needs to be integrated aiming the religious learning not only emphasize on memorization.

2. The Qur'anic dichotomy and nature lead to minimal understanding of Muslims from empirical research products. Muslims only consider the revelation while Westerner considers on nature. Thus, Muslims are quite behind. Though Ibn Shina, Al Farobi, etc. integrating science into Islam (qauliyah) in empirical science (kauniyah). 
3. The dichotomy of revelation and reason. The effect of this dichotomy is the declined of Islamic education because it does not make philosophy as a part of the science that needs to be learned, even philosophy is considered dangerous ${ }^{1}$.

Based on the paradigm and the crisis of educational institutions globally which impact on Islamic educational institutions in Indonesia, it is necessary to find an appropriate alternative to integrate the science of qauliyah with the science of kauniyah. Errors that occur in applying the paradigm of Islamic education following with the concept of Islam and the concept of Indonesia make the educational conceptions from various backgrounds ${ }^{2}$, organize formal educational institutions that integrate religious-knowledge with science.

Based on the assignment decree (SK) for the establishment of SMPIT Alam Nurul Islam, then the school established through the School Establishment Decree: 090 / KPTS / 2013 and Establishment Decree date: 2013-03-04, and Operational Permit Decree: 090 / KPTS / 2013 , and Operational Permit Date : 2013-03-04, NPSN: 60724854 with the address of Gumuk hamlet, Sidoarum, Godean, Sleman Yogyakarta 55564. The development of SMPIT Alam Nurul Islam is quite good and, received predicate " $\mathrm{A}$ " or accreditation with No. Decree of Accreditation: 22.01BAP on 10-22-2015 in 2015.

The vision of SMPIT Alam Nurul Islam is; to be a school that inspires the students to become accomplished, independent, Islamic characters and leader spirits. Meanwhile, the missions are;

1. Create a generation with Islamic characters

2. Organize a natural-based learning

3. Organize education that integrated national education curriculum and Islamic religious curriculum

4. Organize education with a full-day school system

5. Create independent learners

6. Create generations of leaders

7. Create a generation who is trained in solving various problems

8. Emphasize family aspects both in the relationship between the academic community and with the parents.

9. Organize school management with trusted, transparent and promotes accountability.

10. Create an environmentally friendly, clean and presentable of school.

\subsection{SMPIT Alam Nurul Islam; The IT (Islamic-Integrated) with AN (Alam Nusantara)}

Deliberately, the subtitles are structured that aims to comprehensively describe SMPIT Alam Nurul Islam. The SMPIT puts the position of formal education institutions to build the character of students through components that ideally use the paradigm of "Ilmullah", which is grounded in the view that Allah the Almighty revealed the verses and knowledge through two channels, namely formal channels through the procedure of Allah - Angels - prophets or called ayatul Qauliyah (revelation of al Qur'an) which is a guide (minhajul ayah) and ayatul kauniyah which is a facility, means of life (wasailul hayah) [8]. According to Hamdan, the scientists

${ }^{1}$ The results of the chat with Muhammad Hamdani (Manager of the Nurul Islam Foundation for Education) on 4 October 2018 in the library room.

${ }^{2}$ The drafters are: Dr.rer.Nat. Muhammad Farchani Rosyd (Physics Lecturer, UGM), Yuni Erwanto, PhD (Faculty of Animal Husbandry Lecturer, UGM), Murwantoko (Animal Husbandry Lecturer, UGM), Muhammad Hamdan, Dwi Sabda Dwi Prasetyo (former Head of Alam Nurul Islam Junior High School), and Dr. Eko Pujianto. 
proposed the Ayatul Kauniyah and were relative, while Ayatul Qauliyah was mutlaq (absolute) in truth.

SMPIT Alam Nurul Islam is an Integrated Islamic School (IT), as well as Alam Nusantara (AN) school. Thus, it seems that the school is organizing education with fairly burden to students as criticized many parties about 5 days (full-day school) which is tiring for students. Even more, the burden of the school still refers to the national standard curriculum from the Ministry of National Education, the JSIT curriculum, and the local curriculum, namely the teaching of Arabic in 'ulumul qur'an science and 'ulumul hadith. Is it true that students feel burdened in the learning process?

According to an interview with a student of grade IX, this school is a dream school for student and the hopes of the community. Even more, they want to add the school into Senior High level, such as SMAIT Alam Nurul Islam. The answer might be very subjective. But, based on the observations and conversation with some students, the fact, they show cheerful faces. Learners always seem to enjoy following the learning in class, resting, and learning in Mushalla. According to Muhammad Hamdan, the concept of education is fun, cheerful, and not burdened, because the learning is always under the mission.

The integration of SMPIT Nurul Islam is in the application of the curriculum, which is the curriculum compiled by the Ministry of National Education and the curriculum compiled by the Integrated Islamic School Network (JSIT). According to the Head of SMPIT, the idea of integrating Islamic Education (PAI) curriculum is not merely studying Islamic material in its context as 'ulum sya'iyyah but is also positioned as a religious lesson that provides a framework of knowledge, attitudes, and behavior which is relevant and needed in today's life.

The concept of Islamic-Integrated as compiled by JSIT aims to foster the faith through the giving of example, guiding and developing knowledge, comprehension, practice, habituation, realizing Indonesian people who are faith and noble, and instill the spirit of life long education (thalabul 'ilmi) [9].

In the implementation of the curriculum, in general, it has followed the standards, especially the standard facilities and infrastructure, management, and financing. For the analysis, the implementation is related to the implementation of PAI which has the integrated value to build the students' affection, namely: 1) Graduates Competency Standards, 2) Content Standards, 3) Process Standards, 4) Assessment Standards, 5) Educators and Educational Staff Standards.

\section{Graduate Competency Standard (SKL)}

The developed of SKL-SP components are 1) having a straight aqeedah, 2) doing the right worship, 3) having mature and noble character, 4) being a person who is serious, disciplined, and able to perform self-control, 5) has the ability to read, memorize and understand the Qur'an, 6) have broad insights, namely religious and academic knowledge, and 7) have life skills with healthy and fit basic competencies, life skills and entrepreneurial spirit, programs of personal development consisting of leadership and national character, social skills, entrepreneurship, and interests and talents. As for SKL of PAI subjects are used as a reference for learning following the regulation of MGMP PAI and the Ministry of National Education.

\section{Content Standard}

The content standard of PAI learning in SMPIT Alam Nurul Islam is generally the same as in other schools at the Junior High School level, namely integrating the affective, cognitive, and psychomotor domains. The difference is the existence of the Qur'an and the Hadith in a family of Arabic subjects. 


\section{Process Standard}

The standard process developed by SMPIT Alam Nurul Islam is the preparation of the Syllabus following the equivalent school by adding references from the developed learning model in the JSAN curriculum. The preparation of the Lesson Plan more considers the

principles relating to individual differences for students because most of the students come from SDIT which culturally has the same learning motivation, norms, values, and environment.

\section{Learning Implementation}

The learning process in the standard process carried out following the prepared lesson plans and performed either in the classroom or outside the classroom with duration of 40 minutes / 1 hour of learning. According to Hasan Basri (2013: 207), among the characteristics of learning is that can foster attention and motivation, create a safe and pleasant learning atmosphere for students, and emphasize on student activity.

The implementation of PAI learning at SMPIT Alam Nurul Islam is in line with the Lesson Plan and makes the school environment be a source of learning. According to Hayyinatusholihah (Vice of Head), the learning process starts at 08.10 WIB. However, cultural habituation conducts before the learning, which is at $07.00-08.10 \mathrm{WIB}$. Here, there are several activities, such students greet and shake hand with the teacher who stands in front of the inner gate, dzikir ma'tsurat, tahfidz, and duha prayer. After the midday prayer (Zuhr Prayer), continues to Murojaah. And, it conducts dzikir ma'tsurat and preaching after the afternoon prayer (Ashar prayer).

There is a significant difference between the lesson plan model by the Ministry of Education and Culture and the implementation of learning in SMPIT Alam Nurul Islam. The differences are; PAI from the Ministry of Education and Culture is theoretical, while in SMPIT Alam Nurul uses a practical approach. Therefore, students not only understand and memorize but also practice. For example, discussion about the Sunnah prayer, then all the material listed in teaching materials about the Sunnah prayer is not only understood and memorized but practiced. Some things that part of the construction of character building through PAI are;

1. Want the material to be practiced while they have time

2. The material of moral and the situation and condition of the school environment are designed with making the groups to make videos according to the material, such as Qonaah, and students then make Qonaah-themed videos.

3. Form a group of homogenous students to perform mentoring; the mentors are from external (students of UNY) for class IX, and mentors are from internal for class VII and VIII.

According to Jamaludin, all the school situations are learning centers that used as learning sources. Therefore, this PAI teacher was greatly helped by the conditions and situations. These situations are:

1. Educators and educational staff, as well as the gardeners, can be the role models. So, they all behavior reflects the teachings of Islam and might be imitated by the students. This example makes the situation of the school support the creation of expected character education. The term Ustadz/ Ustadzah has its "spirit" in supporting the relationship between teacher and student. 
2. The majority of students are graduated of SDIT. So, they are familiar with the Islamic climate and have built good character and discipline. If the students are not graduated from SDIT, they have to adapt through QUANTUM SALYo ${ }^{3}$ (Yogyakarta Nature School/ Sekolah Alam Yogyakarta) as a 4-day orientation period for students and end with MABIT $^{4}$.

3. Parents have formed a class council that becomes a small halaqoh. This council routinely conducts monthly meetings by inviting teachers of SMPIT. This class council is very helpful in building interaction between parents and the school.

The supporting of PAI learning at SMPIT Alam Nurul Islam is a strategic step for teachers to achieve the learning objectives, among the term of knowledge, attitude (affective), and skills (psychomotor). According to Jamaludin, PAI is a Leading Sector for character building; however, all activities and environments in SMPIT support the characters building of students. Then, the teacher "Duty" is technically very helpful when the learning process aiming to build character within the student is in line with PAI and also supported through extracurricular activities. The activities are;

1. Learning Arabic in 'Ulumul al Qur'an and 'Ulumul hadith in mushalla before learning in class.

2. Friday prayers in schools with the technical ways of 2 times Friday prayer at school and 1 time at a mosque in community.

3. Monday fasting (recommended) and Thursday (Obligated). According to Rizqi (Student), on Monday, there is a ceremony and activities that are quite using energy and thoughtful, then the fasting is only recommended and the school still provides lunch. Meanwhile, on Thursday tends to have a bit of an activity, then the fasting is obligated and the school does not provide lunch and it brought home to break the fast.

4. Dhikr Ma'tsurat every morning before the class.

5. Preaching by students after Asharr prayer in congregation. There are interesting things after preaching, which are;

a. For the first row (shaf) standing and shaking hands with the imam is for students who are reading the Qur'an 3 juz on that day

b. The next place is for students who performed the 4 Rokaat Duha Prayers on that day

c. The next place is for students who performed the 2 rokaat Duha prayers on that day

d. The next place is for students who conduct the fasting sunnah (Thursday)

e. The next place is for students who read al Quran less than 1 juz on that day

\section{Assessment Standard}

Assessment standards as benchmarks in the assessment of PAI learning at SMPIT Alam Nurul Islam use standards that set up or stipulated in the Regulation of Minister of Education and Culture no. 23 of 2016. However, in some material substances, the teachers have own standards, especially relating to local content. The scopes of the assessment of learning outcomes according to regulation of Minister of Education and Culture, number 232016 are the aspect of attitude, knowledge, and skills. These three aspects are added especially attitudes and behaviors that require integration between science and daily charity.

${ }^{3}$ The word of SALYo is what makes SMP Nur Alam Nurul Islam is known as SMPIT SALYo. This program is an acceleration program so students quickly adjust to school habits

${ }^{4}$ MABIT is not only a vehicle for selection of student admissions, but also as a form of routine activities, ideally once a month 
Table 1. Assessment standards as benchmarks for SMPIT in PAI subjects with a more comprehensive proportion of competency achievement assessments.

\begin{tabular}{cccccc}
\hline & & \multicolumn{3}{c}{ PERCENTAGE OF } \\
NO & ASPECT OF PAI & \multicolumn{3}{c}{ FIELD OF ASSESSMENT } & AMOUNT \\
& & Cognitive & Affective & Psychomotor & \\
\hline 1 & Al-Qur'an-Hadith & 25 & 25 & 50 & 100 \\
2 & Akhlak-Faith & 30 & 30 & 40 & 100 \\
3 & Fiqh/Worship & 30 & 30 & 40 & 100 \\
4 & Tarikh & 40 & 40 & 20 & 100 \\
\hline
\end{tabular}

\section{Standards for Educator and Educational Staff}

The standard for educators and educational staff refer to Government Regulation of the Republic of Indonesia Number 32 of 2013 concerning Amendments to Government Regulation Number 19 of 2005 concerning National Education Standards. Standards for educators and educational staff of SMPI Alam Islam Nurul Islam Yogjakarta for PAI teacher are; graduated from the Arabic Faculty of IAIN Yogyakarta and Master from Islamic Education Management at Universitas Muhammadiyah Yogjakarta. Therefore, based on the educational background of the Bachelor is not linear to teach PAI, but the competence and professionalism in teaching PAI subject in SMPIT Alam Nurul Islam is recognized for having taught for quite a long time and including being part of the drafting of the Integrated Islamic School Standards typical book published by JSIT Indonesia. The professionalism and competence of teachers as educators for PAI subject is also based on the experience of teaching religious education at the elementary and secondary level in Japan for 4 years.

\section{Discussion}

SMPIT Alam Nurul Islam is dedicated by the concept of presenting the schools that fully educate children among heart, mind and physical, and skills as well as integrating Islamic values in every subject. The school becomes a student center (student activated) with an experimental learning model and learning by doing, which is students experience and conduct the things in the fun through pleasure learning perspective. On the other hand, SMPIT Alam Nurul Islam is also an Islamic-based school by combining a curriculum compiled by the Islamic-Integrated Schools Network (JSIT) and the Ministry of National Education curriculum. The use of Nature as a school name is as a methodology in teaching, so that the whole school learning process "involves" nature in its environment as a supporting. Nature is used as a learning medium that is quite effective, especially in conditioning students to ignore the boredom experience.

In the perspective of applying Islamic Education (PAI), SMPIT Alam Nurul Islam tries to build affection through Islamic education. Therefore, the instruments used as media to achieve the goals through various methods, such as habituation, practice, rote learning (memorizing), and group formation of similar (homogeneus) students for mentoring. 


\subsection{Implementation of PAI at SMPIT Alam Nurul Islam Yogyakarta}

The implementation of PAI in SMPIT Alam Nurul Islam as previously explained is an integrated curriculum compiled by the Ministry of National Education and Islamic- Integrated School Network (JSIT). The integrated model is not integrated into the "new" curriculum, but rather places the proportion of subject material in the context of school needs. The material compiled by the MGMP of Ministry of Education and Culture continues to deliver following the need for evaluation of learning so that there is no difference with other schools of equal level.

Meanwhile, the practical material compiled by the MGMP of Ministry of Education and Culture is optimally practiced. So, the impression of PAI as the theoretical study does not occur at SMPIT Alam Nurul Islam. Thus, PAI does not merely study Islamic material in its context as 'ulum sya'iyyah but is positioned as a religious lesson that provides a framework of knowledge, attitudes, and behavior that is relevant and needed in today's life. The implementation model of PAI curriculum is following the implementation standards compiled by JSIT which aims to make students become Muslim who have religious awareness following the psychological development of students, religious obedience, noble character, and have the spirit of thalabul 'ilmi (long life).

If examined more deeply, the application of PAI in SMPIT Alam Nurul Islam either the curriculum of the Ministry of Education and Culture or JSIT curriculum goes hand in hand, namely, there is a strengthening in practicing PAI material taught to students. Formally, PAI material is prepared based on the standards of the Ministry of Education and Culture but practically refers to the purpose of providing material formulated in JSIT. Thus, students not only gain Islamic religious knowledge (strong in knowledge) but they are also strong in the application of religious teachings (affective) and behavior in daily life (Psychomotoric).

The strengthening of the implementation of PAI in SMPIT Alam Nurul Islam occurred in the model of habituation and practice in any relevant material or requires practical activities. Examples of this material are material about slaughtering animals that are correct and painless to animals, the practice of eclipse prayer, corpse prayer, etc. The step of developing a theorybased curriculum fully refers to the formulation of material compiled by the Ministry of Education and Culture, while the practice developed in schools is the goal of curriculum development compiled by JSIT in which any PAI teaching material is able of being practiced, it will be practiced.

The implementation of PAI learning at SMPIT Alam Nurul Islam, technically and nontechnically, had no obstacles. The syllabus and lesson plan compiled based on the Ministry of Education and Culture can be taught to students according to the design. Likewise, the practices that are part of the learning process of PAI can run well, even to support the learning process to create an effect on students in a habituation program.

\section{Conclusions}

Based on the results and discussions about SMPIT Alam Nurul Islam; the conclusion of Building Affection through Implementation of Islamic Education are as follows. 
1. Implementation of Islamic education at SMPIT Alam Nurul Islam in Sleman Regency, Yogyakarta refers to the standard curriculum of the Ministry of Education and Culture, JSIT, and JSAN

2. The development of the PAI curriculum is based on integration, especially in the preparation of syllabi, lesson plans, and learning methods. Thus, the development of the PAI curriculum has a good contribution to the development of students' affections, especially through the habituation method.

3. There are various variants in extra-curricular activities that are relevant to the implementation of PAI to form dynamic learning situations and conditions.

4. Some conditions have a very strong supporting capacity for learning of Islamic education, which are the cool condition of nature, natural conditions of habituation, habituation in an Islamic way, creating an academic culture that is blended with the value of religiosity. Through this kind of conditioning, gives the impression that there are no technical or nontechnical obstacles in the implementation of PAI to build student affection.

\section{References}

[1] Mochtar Buchori: Transformasi Pendidikan. Pustaka Sinar Harapan-IKIP Muhammadiyah Press. Jakarta. (2015)

[2] Darmaningtyas: Pendidikan Rusak-rusakan. LkiS. Yogyakarta. (2007)

[3] Nasution: Asas-asas Kurikulum. Bumi Aksara. Jakarta. (2008)

[4] Kelvin Seifert: Pedoman Pembelajaran \& Instruksi Pendidikan. IRCiSoD. Jogjakarta. (2012)

[5] Oemar Hamalik: Dasar-dasar Pengembangan Kurikulum. PT Remaja Rosdakarya. Bandung. (2008)

[6] Andrias Harefa: Menjadi Manusia Pembelajar: On Becoming Learner. Harian Kompas. Jakarta. (2000)

[7] M. Hamdar Arraiyah \& Jejen Musfah (ed.): Pendidikan Islam; Memajukan Umat dan Memperkuat Kesadaran Bela Negara. Kencana. Jakarta. (2016)

[8] Syukro Muhab, dkk: Standar Mutu Sekolah Islam Terpadu. JSIT Indonesia Empowering Islamic Schools. Jakarta. (2010)

[9] Syukro Muhab, dkk: Standar Mutu Kekhasan Sekolah Islam Terpadu. (2017)

[10] Sugiyono: Metode Penelitian Pendidikan Pendekatan Kuantitatif, Kualitatif, dan R\&D. Bandung: Alfabeta. (2014) 